\title{
THE CHARACTERIZATION OF FIRES IN RELATION TO ECOLOGICAL STUDIES
}

\author{
A.G. McArthur and N.P. Cheney \\ Forest Research Institute, Canberra, Australia
}

\section{INTRODUCTION}

Literature dealing with the effects of fire on vegetation and soil has been adequately summarized by Hare (1961). In some two hundred references there is almost a complete absence of a precise description of the type of fire causing the various effects described.

The pioneer Australian study of the effect of fire on soil temperature by Beadle (1940), although not describing the type of fire adequately, at least described the type of fuel in which the fires burnt and gave some dimensions whereby a reasonable estimate of the fire energy could be determined.

Even in very recent studies of fire effects, little attention has been given to a description of the fire which produced the published results. Uggla (1960) talks in general terms of "feeble forest fires" and describes soil heating effects from a number of undefined test fires. Yet the paper states that "the severity of the fire is dependent on several factors such as forest type, the quantity and composition of combustion material and the strength of the wind."

Byram (1959) was the first to recognise the need for a precise definition of fire behaviour. $\mathrm{He}$ introduced terms such as available fuel energy, total fuel energy, fire intensity, total fire intensity, and combustion rate. All these can be used "to define specific combustion and fire behaviour terms and establish units of measurements which thus far have been used in a general sense only."

The fire behaviour terms defined by Byram were used by McArthur (1962) to describe prescribed burning conditions in eucalypt forests and by Van Wagner (1964) to characterize a fire in red pine stands in Ontario. The fire energy concept has been enlarged on by Van Wagner (1965).

It is now generally accepted that four primary factors must be specified before possible effects of fire on vegetation or soil can be considered. These are:

(1) Fire frequency.

(2) Heat intensity and duration.

(3) Fuel bed characteristics.

(4) Soil and vegetation characteristics.

The purpose of this paper is to outline quantitative methods of describing fires which are meaningful for the purpose of considering fire effects on vegetation, soil or microfaunal activity.

\section{THE FIRE ENERGY CRITERIA}

Fire behaviour can be described in such terms as rate of forward spread, flame height, scorch height, ground fire, crown fire, and so on. A fire may be described as "cool" or "hot" or of "low intensity" or "high intensity." These are purely qualitative expressions and in no way indicate the damage potential of a fire. If a measure of fuel quantity was introduced, rate of spread would be the most adequate of the above descriptions.

The fire energy or fire intensity concept developed by Byram (1959), is one of the most complete descriptions of a fire which is meaningful in terms of the damage it can do under a specific set of circumstances. Fire intensity is the rate of energy release or rate of heat release per unit time, per unit length of 
fire front. Fire intensity can be expressed by a simple equation.

$$
\mathrm{I}=\mathrm{Hwr}
$$

where $\mathrm{I}=$ fireline intensity in $\mathrm{kW} \mathrm{m} \mathrm{m}^{-1}$ of fire front, $\mathrm{H}=$ heat yield in $\mathrm{kJ} \mathrm{kg}^{-1}$ of fuel, $\mathrm{w}=$ weight of available fuel in $\mathrm{kg} \mathrm{m}^{-2}$, and $\mathrm{r}=$ rate of forward spread in $\mathrm{m} \mathrm{sec}^{-1}$.

Fire intensity can vary from $17 \mathrm{~kW} \mathrm{~m}^{-1}$ to around $103000 \mathrm{~kW} \mathrm{~m}^{-1}$ in forest and grassfires. However, the more normal intensity range for a grassfire would be $17 \mathrm{~kW} \mathrm{~m}^{-1}$ to 24 $000 \mathrm{~kW} \mathrm{~m}^{-1}$.

In the intensity range of $17 \mathrm{~kW} \mathrm{~m}^{-1}$ to 350 $\mathrm{kW} \mathrm{m}{ }^{-1}$ little damage is done to forest trees although some significant ecological changes can occur in this range. Many Australian species, particularly members of the Proteaceae, Myrtaceae and Casuarinaceae can be killed by these low intensity fires but little seedling regeneration will result as the fire is not hot enough to induce germination. Dogwood (Cassinia aculeate [Labill.] R.Br.) is another fire weed species which can be killed by a remarkably low intensity fire. Many of these species are highly inflammable and are undesirable fire fuel components.

In the intensity range $350 \mathrm{~kW} \mathrm{~m}^{-1}$ to 1700 $\mathrm{kW} \mathrm{m} \mathrm{m}^{-1}$ some slight physical damage to eucalypt and coniferous species occurs. Some ultimate branchlets on more fire sensitive eucalypts may be killed and occasional log degrade in the form of gum veins may occur.

Fires in the intensity range of $1700 \mathrm{~kW} \mathrm{~m}^{-1}$ to $3500 \mathrm{~kW} \mathrm{~m}^{-1}$ generally cause physical damage to the bole and crown of eucalypts and some timber degrade is likely. Loss of increment due to crown scorch will occur in the more fire sensitive species. Young regeneration up to $4.5 \mathrm{~m}$ in height may be killed. A fire intensity of $3500 \mathrm{~kW} \mathrm{~m}^{-1}$ is about the maximum that a Pinus radiata D.Don plantation can stand without causing some tree deaths. However, Pinus elliottii Engelm. can withstand a fire intensity of $3500 \mathrm{~kW} \mathrm{~m}^{-1}$ to 7000 $\mathrm{kW} \mathrm{m}{ }^{-1}$, without causing death of mature trees.
A $2 \mathrm{yr}$ to $3 \mathrm{yr}$ loss of increment will result from a fire of this intensity.

The expression of fire intensity gives the rate of energy output of each meter of the fire front, and may at first appear a little complicated. However, the three variables in the equation are easily measured and provide a precise means of estimating the damage potential of a fire.

Heat yield or heat of combustion is fairly constant over a wide range of natural fuels and can generally be taken as $14000 \mathrm{~kJ} \mathrm{~kg}^{-1}$ to $15000 \mathrm{~kJ} \mathrm{~kg}^{-1}$ of fuel. It varies slightly with fuel moisture content and may be reduced due to incomplete combustion in a fast spreading, high intensity fire.

The second term, weight of fuel consumed, is difficult to estimate, and generally requires measurement. However, reasonably precise ocular estimates can be made with some practice. The range of fuel quantity is not great in natural fuels and may range from $4.5 \mathrm{Mg} \mathrm{ha}^{-1}$ to around $45 \mathrm{Mg} \mathrm{ha}^{-1}$ in exceptionally heavy, long unburnt fuels. In the absence of fuel quantity measurements, yardsticks such as time since last burn, fuel depth and fuel continuity may be used to estimate roughly fuel quantity.

Fuel availability is complicated by rain effects and the relationship between total fuel and available fuel will be discussed later.

Rate of forward spread of a fire varies considerably and may range from $<1 \mathrm{~m} \mathrm{sec}^{-1}$ to 1 $\mathrm{m} \mathrm{sec}^{-1}$ in the case of a fire burning in eucalypt forest or from $<1 \mathrm{~m} \mathrm{sec}^{-1}$ to $6.1 \mathrm{~m} \mathrm{sec}^{-1}$ in the case of a grassfire. However, it is the easiest of the three variables determining fire intensity to measure providing some time record of the fire is available.

Fire intensity, expressed in $\mathrm{kW} \mathrm{m}^{-1}$ of fire front should be associated with specific fire behaviour characteristics such as flame height, scorch height, rate of spread and damage.

Beyond intensities of $3500 \mathrm{~kW} \mathrm{~m}^{-1}$, physical damage to the standing forest varies widely according to the heat tolerance of individual species. Most understory species will be killed 
by the fire but most will coppice or regenerate heavily from seed.

The relationship between fire intensity and damage to a 40 year-old pole stand of jarrah (E. marginata Donn. Ex. Sm.) is shown in Figure 1. Jarrah is one of the most fire resistant eucalyptus species and the data is derived from damage incurred in the Dwellingup Fire of January, 1961. The estimate of physical damage is expressed in terms of final crop potential. A damage assessment of $100 \%$ means that no trees in the stand will make final crop trees due either to death or severe log degrade. It seldom means that all trees are killed. A $50 \%$ assessment of physical damage indicates that sufficient trees remain for a final crop, but most will carry severe fire scars and there will be at least $20 \%$ loss of timber due to degrade, and an absolute loss of 5 years increment.

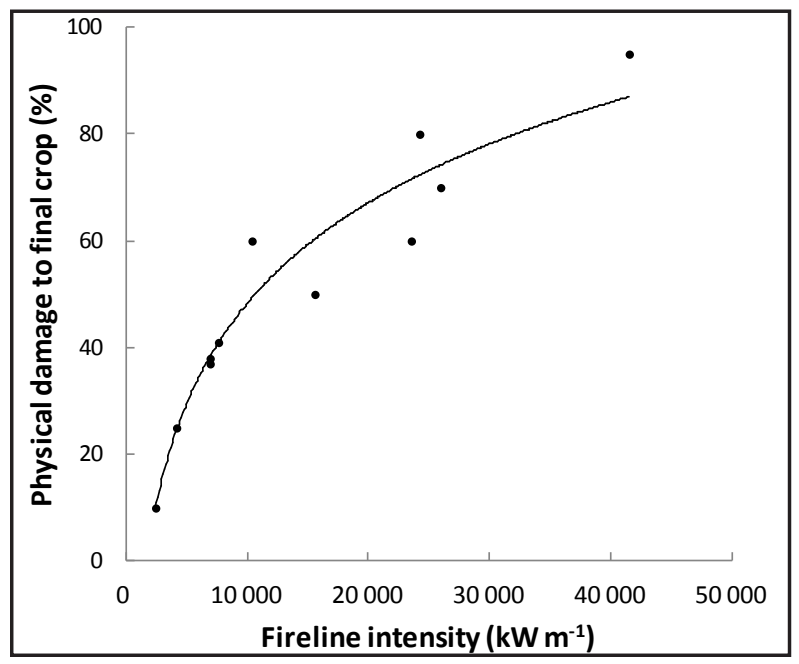

Figure 1. Relationship between fire intensity and physical damage to final crop potential in a polesized 40 year-old stand of jarrah (E. marginata).

The same study related monetary loss per acre to fire intensity and these values are shown in Figure 2. This loss is in terms of commercial timber and does not include other values such as watershed or recreation.

The fire intensity is generally calculated for the headfire region and intensity on the sides and rear of a fire will be much lower due to

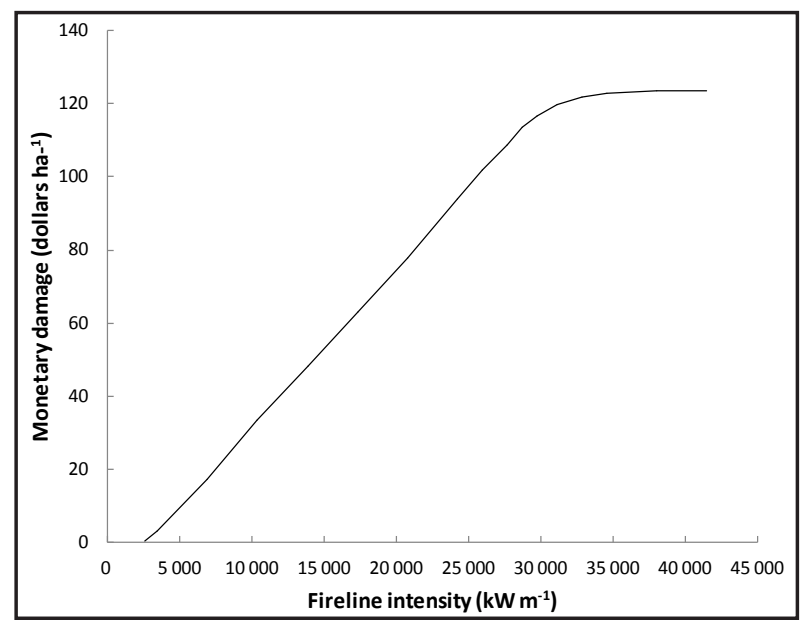

Figure 2. Relationship between monetary loss (mid1960s Australian dollars) and fire intensity in a polesized 40 year-old stand of jarrah (E. marginata).

slower rates of spread. The headfire zone generally embraces no more than one third to one half of the total area burnt by an individual fire and the fire damage assessed for the headfire region should not apply to the whole fire area.

The fire intensity concept has an important advantage in that it can be readily calculated without having seen the fire, provided the rate of spread and fuel consumption per unit area is known.

Fire danger rating systems for Forest Fuel Types developed by McArthur (1963) are based on rate of spread derived from meteorological and fuel factors and can be related directly to fire intensity. This system is in the form of a simple slide rule and could be readily applied to ecological fire studies. Cheney (1965) has further enlarged on the fuel energy concept involved in this system of fire danger rating.

\section{FUEL AVAILABILITY}

Fuel quantity is one of the major variables affecting fire behaviour. For a given set of meteorological conditions rate of forward progress of a fire is directly related to the quantity of fuel available for combustion. As 
fuel quantity doubles, rate of spread will double and fire intensity will increase fourfold.

Fuel quantity affects all aspects of fire behaviour such as rate of spread, fire intensity, flame height, scorch height, crownfire formation, the spotting process and through all these, the damage resulting from the fire.

Two concepts of fuel availability are required before specific damage effects of a fire can be considered.

"Available fuel" is the quantity of fuel which is consumed in a fire. It is subject to wide variation and even in a relatively uniform fuel type the available fuel will depend on the moisture content of the individual fuel components. If the fuel complex has a moisture gradient due to the influence of recent rain, then only a proportion of the total fuel will burn. This is the whole basis of prescribed burning where the technique is to burn when the lower fuel bed and the large fuel components are moist. Thus only a proportion of the total fuel is consumed and fire intensity is kept to prescribed limits. Even under mild meteorological conditions, if all the fuel is dry enough to burn, it is frequently impossible to carry out prescribed burning in heavy fuel accumulation without doing damage.

The quantity of fuel consumed in a fire also varies with the intensity of the fire and more fuel is usually consumed in a fast running headfire than in a slow moving headfire, or in a fire spreading against the wind.
"Total fuel" is the quantity of fuel which would burn under the driest conditions with a high intensity fire. This sets a worst-possible or maximum value for available fuel.

The quantity of fuel consumed in a fire also depends on fuel arrangement and a duration effect. It is possible to pile large logs in a slash heap mixed with finer and drier fuel components and have most of the fuel components completely consumed. Under natural conditions of a moving flame front, these larger components are seldom consumed. The longer duration of the fire and the arrangement of the fuel components gives more effective heat transfer and the rate of drying of the larger components is sufficiently rapid for combustion to take place.

The change in fuel availability is illustrated by recent figures from fire behaviour studies in $P$. radiata fuel types (Table 1 ).

In this study experimental fires were burnt on successive days after heavy rain in a fuel complex which is in a drying cycle. Changes in fire intensity and damage effects associated with increasing fuel availability can be readily studied under these conditions.

The $P$. radiata stand has been thinned and the fuel complex is extremely heterogeneous due to uneven logging slash accumulation. However, the figures do indicate the dramatic changes which took place in fuel availability.

Logs greater than $7.6 \mathrm{~cm}$ diameter are excluded from the analysis because they are sel-

Table 1. Fuel components in a 23 year-old stand of $P$. radiata pruned and thinned and subjected to fires of varying intensities.

\begin{tabular}{|c|c|c|c|c|c|c|c|}
\hline \multirow[b]{2}{*}{ Treatment } & \multicolumn{7}{|c|}{ Fuel components $\left(\mathrm{Mg} \mathrm{ha}^{-1}\right)$} \\
\hline & $\begin{array}{c}\text { Plots } \\
(n)\end{array}$ & $\begin{array}{c}\text { Needles and twigs } \\
<0.062 \mathrm{~cm}\end{array}$ & $\begin{array}{c}\text { Twigs } \\
0.63 \text { to } 2.54 \mathrm{~cm} \\
\end{array}$ & $\begin{array}{c}\text { Branches } \\
2.55 \text { to } 7.62 \mathrm{~cm} \\
\end{array}$ & Duff & Total & $\begin{array}{c}\text { Total fuel } \\
\text { consumed (\%) }\end{array}$ \\
\hline Unburnt & 6 & 6.1 & 6.7 & 12.8 & 12.8 & 38.3 & 0.0 \\
\hline \multicolumn{8}{|l|}{ Burnt } \\
\hline $1 \mathrm{~d}$ after rain & 4 & 2.0 & 8.5 & 12.6 & 9.0 & 32.1 & 16.3 \\
\hline $2 \mathrm{~d}$ after rain & 7 & 1.3 & 7.2 & 13.0 & 11.0 & 32.1 & 15.2 \\
\hline $14 \mathrm{~d}$ after rain & 2 & 0.0 & 3.1 & 9.9 & 3.8 & 16.8 & 55.0 \\
\hline $30 \mathrm{~d}$ after rain & 2 & 0.0 & 0.9 & 4.3 & 2.4 & 7.4 & 80.6 \\
\hline
\end{tabular}


dom consumed in a fire. In this stand the large $\log$ component averages around $9 \mathrm{Mg} \mathrm{ha}^{-1}$.

The only fuel components consumed in a very moist fuel complex are needles and small twigs. As the fuel mass dries, the larger components become available for combustion and add to the available fuel. After 14 days larger twigs and branches burn and the duff layer has dried out sufficiently to burn. Under very dry conditions only the larger branches and the bottommost layer of duff are not consumed. The fire has virtually burnt down to mineral soil and under these conditions fire damage would be accelerated.

The change in fire behavior characteristics and fire intensity resulting from this increased fuel availability is shown in Table 2.

If fire intensity rose to above $7000 \mathrm{~kW} \mathrm{~m}^{-1}$ in this particular fuel type, a crown fire would develop and the green crowns would be consumed. This fuel component would add around $6.7 \mathrm{Mg} \mathrm{ha}^{-1}$ to available fuel and a wall of flames $18 \mathrm{~m}$ to $24 \mathrm{~m}$ high would develop.

The maximum rate of forward progress in this fuel type would be around $0.6 \mathrm{~m} \mathrm{sec}^{-1}$ and the fire intensity around $110000 \mathrm{~kW} \mathrm{~m}^{-1}$-a tremendous rate of energy release. This gives some indication of the range of fire intensity possible in these coniferous forests.

\section{FIRE DURATION}

The duration of flaming combustion over a unit area has a very significant effect on damage to living vegetation and heat penetration into the soil.

The burnout time or residence time of a fire depends on the rate of spread of the fire, the quantity of fuel available for combustion, and the combustion rate of the fuel. Thus for a specific fuel, it is directly related to fire intensity.

Combustion rate varies to some extent according to the moisture content of the fuel but is mainly a function of fuel particle size. Combustion rates for some typical fuels are given in Table 3.

Knowing the quantity of fuel available for combustion, it is a simple calculation to determine the period over which flaming combustion will take place.

Burnout time $(\mathrm{s})=$

Heat yield $\left(\mathrm{kJ} \mathrm{kg}^{-1}\right) \times$ Fuel quantity $\left(\mathrm{kg} \mathrm{m}^{-2}\right)$

$$
\text { Combustion rate }\left(\mathrm{kW} \mathrm{m}^{-2}\right)
$$

Thus for a fuelbed of eucalyptus litter carrying $22.4 \mathrm{Mg} \mathrm{ha}^{-1}$ of available fuel, the burnout time would be

Table 2. Changes in fire behaviour resulting from increased fuel availability in $P$. radiata stands.

\begin{tabular}{|c|c|c|c|c|c|c|}
\hline Treatment & $\begin{array}{l}\text { Total fuel } \\
\left(\text { Mg ha }^{-1}\right)\end{array}$ & $\begin{array}{l}\text { Fuel consumed } \\
\left(\mathrm{Mg} \mathrm{ha}^{-1}\right)\end{array}$ & $\begin{array}{l}\text { Rate of forward } \\
\text { progress }\left(\mathrm{m} \mathrm{s}^{-1}\right)\end{array}$ & $\begin{array}{c}\text { Flame height } \\
\text { (m) }\end{array}$ & $\begin{array}{c}\text { Flame depth } \\
\text { (m) }\end{array}$ & 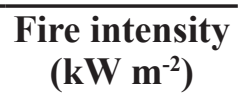 \\
\hline $1 \mathrm{~d}$ after rain & 38.3 & 6.3 & 0.025 & 0.3 & 0.6 & 232 \\
\hline $2 \mathrm{~d}$ after rain & 38.3 & 5.8 & 0.025 & 0.6 & 0.8 & 291 \\
\hline $14 \mathrm{~d}$ after rain & 38.3 & 21.1 & 0.048 & 1.2 & 1.8 & 1868 \\
\hline $30 \mathrm{~d}$ after rain & 38.3 & 30.9 & 0.066 & 2.7 & 4.6 & 3874 \\
\hline
\end{tabular}

Table 3. Combustion rates for typical Australian fuel types determined from experimental fire behaviour studies.

\begin{tabular}{|c|c|}
\hline Fuel type & Combustion rate $\left(\mathrm{kW} \mathrm{m}^{-2}\right)$ \\
\hline Eucalypt leaves and twigs & 249.7 \\
\hline P. radiata needles and twigs & 397.3 \\
\hline Wheat stubble & 919.3 \\
\hline Improved pasture (rye grass and clover) & 1702.5 \\
\hline
\end{tabular}




$$
\frac{15106 \times 2.24}{249.7}=136 \mathrm{~s}
$$

In comparison the burnout time for a grassfire in an average fuel quantity of $4.5 \mathrm{Mg} \mathrm{ha}^{-1}$ would only be about $4 \mathrm{~s}$.

As heat penetration into the soil and through the bark of living vegetation is closely related to burnout time or flame persistence, the damage potential of the eucalypt fire is much greater than the grassfire.

The use of the fire intensity concept to characterize fire in terms of potential damage can only be applied to a moving flame front.

As many studies of fire effects have been confined to stationary fires such as burning slash piles, the damage potential of these fires can be determined from the burnout time which incorporates both fire intensity and duration effect.

A pile of eucalypt logs would be expected to have a combustion rate of around $11 \mathrm{~kW} \mathrm{~m}^{-2}$ to $23 \mathrm{~kW} \mathrm{~m}^{-2}$. If the fuel loading is $112 \mathrm{Mg}$ $\mathrm{ha}^{-1}$ or $11.2 \mathrm{~g} \mathrm{~m}^{-2}$, the burnout time would be

$\frac{15106 \times 11.21}{11.35}=14920 \mathrm{~s}($ or $248 \mathrm{~min}$ or $4.15 \mathrm{~h})$.

This is a reasonably modest pile of logs and fuel quantities in the order of $672 \mathrm{Mg} \mathrm{ha}^{-1}$ are quite common in heavy slash fires. Such a quantity of fuel would have a burnout time of $27 \mathrm{~h}$, producing a tremendous heat flux to considerable depth in the soil.

\section{CONCLUSION}

The most meaningful expression of a fire in terms of potential damage to vegetation and soil is given by the fire energy concept. This is related to rate of spread, heat yield of the fuel and the quantity of fuel available for combustion.
Burnout time or flame persistence is an important fuel characteristic related largely to fuel particle size. Heavier fuels such as eucalypt litter have burnout times ranging up to several minutes, whereas the so-called "flash fuels" such as grass, burnout in a few seconds. Heat penetration into the soil and damage to vegetation is directly related to this duration effect.

In any specific fuel type physical damage to the vegetation and monetary damage to a commercial forest crop is directly related to the fire intensity.

The characterization of a stationary fire, typified by a burning slash pile is best expressed by burnout time calculated from heat yield, fuel quantity and combustion rate. Long duration effects are typical of these fires and soil heating can reach high values at depths exceeding $30 \mathrm{~cm}$ to $43 \mathrm{~cm}$.

Little attention has been given in this paper to the effect of fire frequency on vegetation or soil changes or to the effect of the physical properties of soils or to the heat tolerance of different species. All these are important variables and must be considered together with the fire energy before possible effects of fire on vegetation or soil can be determined.

This paper was originally published in Australian Forest Research 2(3): 36-45. It has been slightly reformatted to conform to journal standards, including conversion to SI units. 


\section{LITERATURE CITED}

Beadle, N.C.W. 1940. Soil temperatures during forest fires and their effect on the survival of vegetation. Journal of Ecology 28: 180-192. doi: 10.2307/2256168

Byram, G.M. 1959. Combustion of forest fuels. Pages 61-89 in: K.P. Davis, editor. Forest fire: control and use. McGraw Hill, New York, New York, USA.

Cheney, N.P. 1965. Problems in the application of McArthur's Fire Danger Index. Department of National Development, Forestry and Timber Bureau, Canberra, Australia.

Hare, R.C. 1961. Heat effects on living plants. USDA Forest Service Occasional Paper 183, Southern Forest Experiment Station, New Orleans, Louisiana, USA.

McArthur, A.G. 1962. Control burning of eucalypt forests. Department of National Development, Forestry and Timber Bureau Leaflet 80, Canberra, Australia.

McArthur, A.G. 1963. Forest fire danger meter. Department of National Development, Forestry and Timber Bureau, Canberra, Australia.

Uggla, E. 1960. Ecological effects of fire on north Swedish forests. Pages 994-997 in: Proceedings of the fifth world forestry congress, volume II. Food and Agriculture Organization of the United Nations, 29 Aug-10 Sep 1960, Seattle, Washington, USA.

Van Wagner, C.E. 1964. History of a small crown fire. Forestry Chronicle 40: 202-209. doi: $10.5558 / \mathrm{tfc} 40202-2$

Van Wagner, C.E. 1965. Describing forest fires - old way and new. Forestry Chronicle 41:301305. doi: $10.5558 / \mathrm{tfc} 41301-3$ 